\title{
Abrupt vessel closure after diagnostic contrast injection at the site of coronary computed tomography angiography identified silent plaque rupture
}

Nagłe zamknięcie naczynia po podaniu kontrastu w miejscu pękniętej blaszki miażdżycowej zidentyfikowanej w badaniu metodą tomografii komputerowej tętnic wieńcowych

\author{
Rafał Wolny ${ }^{1}$, Jerzy Pręgowski ${ }^{1}$, Maciej Dąbrowski ${ }^{1}$, Cezary Kępka², Adam Witkowski ${ }^{1}$ \\ 1Department of Interventional Cardiology and Angiology, Institute of Cardiology, Warsaw, Poland \\ 2Department of Coronary and Structural Heart Diseases, Institute of Cardiology, Warsaw, Poland
}

Postep Kardiol Inter 2012; 8, 3 (29): 244-245 DOI: $10.5114 /$ pwki.2012.30404

Key words: vessel closure, coronary computed tomography angiography, plaque rupture

Słowa kluczowe: zamknięcie naczynia, tomografia komputerowa tętnic wieńcowych, pęknięta blaszka miażdżycowa

Coronary computed tomography angiography (CCTA) scanning was performed in a 53-year-old woman, who presented to the Cardiology Department with typical retrosternal pain on exertion persisting for 6 months. A heterogeneous lesion ( $80 \%$ stenosis) was found in the proximal left anterior descending artery (LAD) (Figures $1 \mathrm{~A}$ and $B$ ). Two bright dots of contrast in its main burden were interpreted as ulcerations (Figure $1 \mathrm{C}$, white arrows), which led to the suspicion of plaque rupture.

Subsequent coronary catheterization revealed significant stenosis in the proximal LAD with no signs of lesion complexity (Figure 1 D). Unexpectedly, the third consecutive injection of contrast medium resulted in sudden occlusion of the vessel at the lesion site with TIMI 0 flow (Figures $1 \mathrm{E}$ and F). Fortunately, an immediate attempt of recanalization was successful and blood flow was restored. After predilatation an everolimus-eluting 2.5/20 $\mathrm{mm}$ stent was implanted in the lesion site resulting in TIMI 3 flow.

During observation of the patient in the intensive care unit, the chest pain recurred once, with transient ECG evidence of myocardial ischemia in leads $V_{4}-V_{6}$. However, control MSCT examination confirmed the good result of $\mathrm{PCl}$. Further follow-up was uneventful. Echocardiography revealed apical hypokinesis and the cardiac MRI performed a month later confirmed a post-infarct scar in the apical segment of the heart.
We suppose that the sudden closure of the previously damaged vessel segment with unstable ruptured plaque was triggered by the rapid flow of the contrast medium. Since it is possible to detect silent ruptured plaques in CCTA, such findings should incline the operators to perform very careful contrast injection in order to prevent serious complications. 


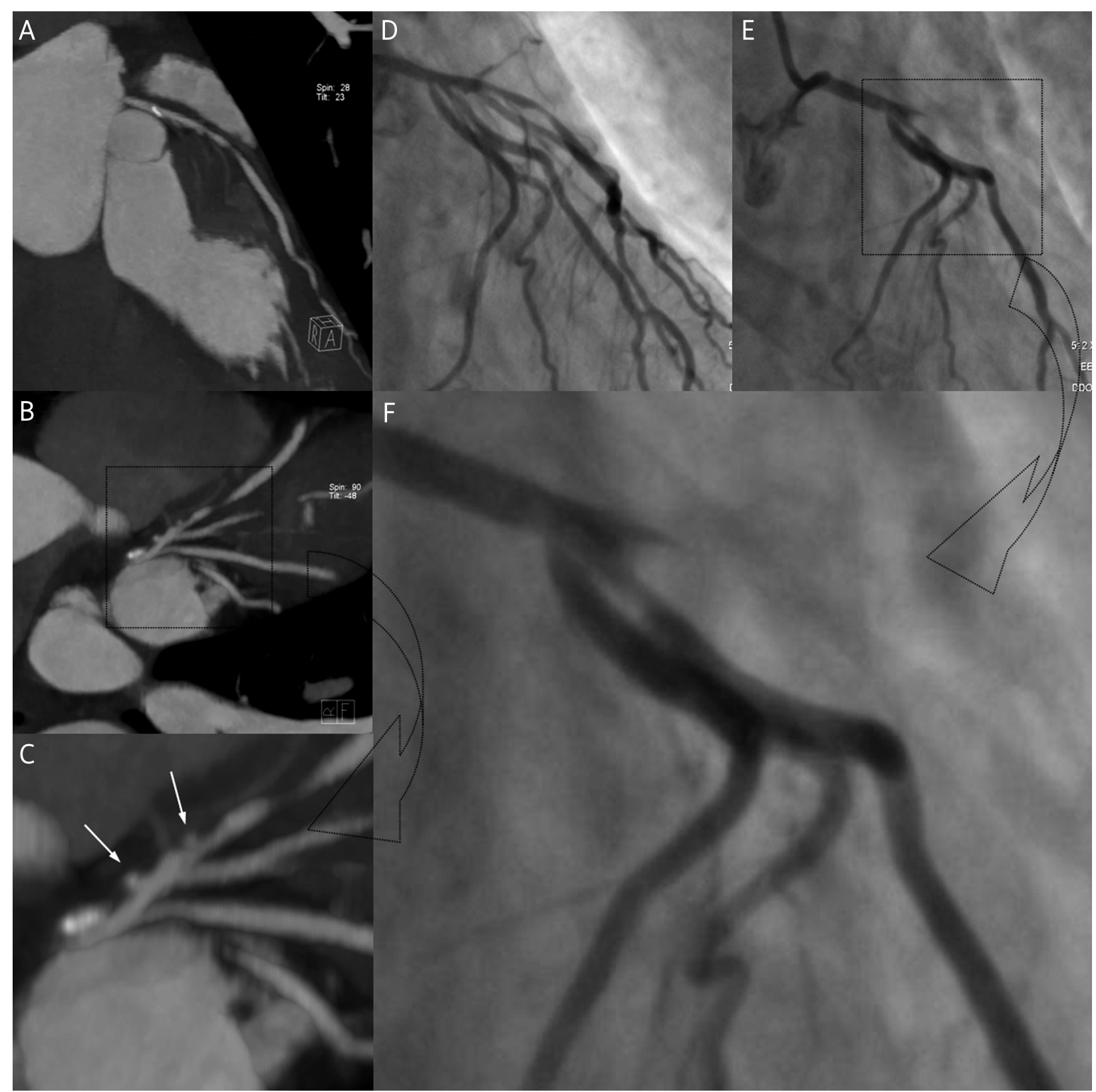

Fig. 1. CCTA and invasive angiography images of proximal LAD lesion. $A$ and B - CCTA reconstructions showing tight stenosis in the proximal LAD segment; $C$ - proximal LAD lesions with two sites of plaque rupture (arrows); $\mathrm{D}$ - invasive angiography documenting proximal LAD stenosis - first contrast injection; $\mathrm{E}$ and $\mathrm{F}$ - abrupt closure of the proximal LAD following third contrast injection

Ryc. 1. Obrazy proksymalnego segmentu gatęzi przedniej zstępującej (GPZ) uzyskane za pomocą tomografii komputerowej tętnic wieńcowych oraz koronarografii. A i B - rekonstrukcje tomograficzne ukazujące ciasne zwężenie w proksymalnym semencie GPZ, C - zwężenia w proksymalnym segmencie GPZ z dwiema zmianami o morfologii pękniętej blaszki miażdżycowej (strzatki), D - koronarograficzny obraz zwężenia w proksymalnym segmencie GPZ (pierwsze podanie kontrastu), E i F-obraz zamknięcia naczynia w proksymalnym segmencie GPZ po trzecim podaniu kontrastu 